\title{
CASH HOLDING, GOOD CORPORATE GOVERNANCE AND FIRM VALUE
}

\author{
Prana Wahyu Nisasmara, Musdholifah
}

Faculty of Economic, Universitas Negeri Surabaya, Surabaya, Indonesia

\begin{tabular}{l} 
Info Article \\
\hline History Article: \\
Received Juni 2016 \\
Approved July 2016 \\
Published September 2016 \\
\hline Keywords: \\
Firm Value; \\
Profitability; \\
Capital Structure; \\
Cash Holding; \\
Good Corporate Governance
\end{tabular}

Good Corporate Governance

\section{CASH HOLDING, GOOD CORPORATE ORVERNANCE, DAN NILAI PERUSAHAAN}

\begin{abstract}
The company's main goal is to maximize the long term value of the company. The company's ability to generate value for the company was favorably affected by management's ability to manage the company. The company expects the financial manager will do the best for the company to increase the value of the company and create wealth for owners and shareholders. This research aims to understand the influence of profitability, capital structure, cash holding, and GCG (Good Corporate Governance) on firm value. The samples of this study were the property sector and real estate companies listed on Indonesia Stock Exchange (IDX) in the period of 2008-2013. The data used from the annual report company. The methods of data analysis were multiple regression models and analyzed using IBM SPSS software. The results of this study are profitability has no influence on firm value, capital structure has positive influence on firm value, cash holding has no influence on firm value and GCG a has a positive influence on firm value.
\end{abstract}

\begin{abstract}
Abstrak
Tujuan utama perusahaan adalah memaksimalkan nilai jangka panjang perusahaan. Kemampun perusahaan dalam menghasilkan nilai lebih dipengaruhi dari kemampuan manajemen dalam mengelola perusahaan. Perusahaan mengharapkan manajer keuangan mampu melakukan hal yang terbaik untuk meningkatkan nilai perusahaan dan menciptakan kesejahteraan bagi pemilik dan pemegang saham. Penelitian ini bertujuan untuk menganalisis pengaruh profitabiltas, struktur modal, cash holding, dan GCG (Good Corporate Governance) terhadap nilai perusahaan. Sampel yang digunakan dalam penelitian ini adalah perusahaan sektor properti dan real estate yang terdaftar di Bursa Efek Indonesia periode 2008-2013. Metode analisis yang digunakan adalah regresi linier berganda. Hasil penelitian ini menunjukkan bahwa profitabilitas dan cash holding tidak berpengaruh terhadap nilai perusahaan, sedangkan struktur modal dan GCG berpengaruh positif terhadap nilai perusahaan sektor properti dan real estate di Indonesia.
\end{abstract}

JEL Classification: G3, G32

\footnotetext{
${ }^{\otimes}$ Correspondence Address

Email: musdholifah@unesa.ac.id
} 


\section{INTRODUCTION}

Companies as an economic institution have short-term and long term goals. In the short-term, the company aims to earn a return to the maximum by using existing resources. The company's main goal is to maximize the long term value of the company. The company's ability to generate value for the company was favorably affected by management's ability to manage the company. The company expects the financial manager will do the best for the company to increase the value of the company and create wealth for owners and shareholders. Companies with good performance will reflect the company's good value too. This can be reflected in the stock price. According to Sari (2013) the value of the company is reflected in the stock price is a market perception from investors, creditors and other stakeholders on the condition of the company.

Potential investors get an idea on the value of assets owned by a company through the stock price. If the stock price increases, the value will rise and vice versa. This information is useful to investors in making investment decisions. In this case, the investor considers that profitability has objective value for making investment decisions. Profitability is the result obtained through the efforts of the management of funds invested shareholders. Investors can also determine the ability of the company in return on investment and dividend payment in cash or shares to investors through the company's profitability. This will push the stock price has increased.

Shares of companies that have a high level of profitability will be more attractive to investors than companies with low profitability levels. High profitability also shows the company's prospects are good, so it will create a positive sentiment for the shareholders that the company's value will increase (Sujoko \& Soebiantoro 2007). Profitability gives an objective value of the value of investments in a company. Therefore, the profit of a company is the hope for investors, but investors also need to be careful in determining investment decisions. This is because if the decision incorrect, the investor not only loses return but also all the initial capital invested will be lost (Astuti \& Setiawati, 2014).

Santi (2011) showed that the positive effect on the profitability of the company's value. The results of this study stated that the greater the profits, the greater the company's ability to pay dividends. Furthermore \& Yuliana (2013), Wardoyo and Veronica (2013), Astuti and Setiawati (2014) also stated that profitability had a significant positive relationship to the value of the company. However, Wibowo and Aisjah (2014) reported the results of different studies that partially profitability has no significant effect on the value of the company. Similarly, Sambora (2014) shows that profitability has a negative correlation and no significant effect on the value of the company. Results of research Mardiyati et al. (2012) reported that the higher the profit value obtained, the higher the value of the company. Due to the high profit will give an indication of the company's prospects are good, so it can lead investors to increase demand for stocks. Demand rising stocks will cause the value of the company increases.

As for the other factors that affect the value of the company is its capital structure. According to Wahyuni (2012) capital structure is essential for any company, because of the good and bad capital structure will have a direct effect on the financial position of the company. Today, the business world is highly dependent on funding issues. Therefore, the company's managers are expected to take effective measures in determining the capital structure. The goal is to achieve the company goal that is to maximize the value of the company. Companies can obtain the funding requirements from both internal and external. The funds will be used to strengthen the capital structure of the company, so the company is able to control capital appropriately.

The decision to choose the source of funds used to strengthen the capital structure of a company is a simple decision, but it has strong 
implications for what will happen in the future. Capital structure decision has an effect on the financial position of the company, which in turn will affect the value of the company. Based on the theory of capital structure, if the position of the target capital structure is above the optimal capital structure, then each increment of debt would lower the value of the company (Kusumajaya, 2011).

Antwi et al. (2012) showed that the capital structure significantly influences the value of the company. This statement is supported by the results of Chen (2002), Chowdhury and Chowdhury (2010), Santi (2011), Hoque et al. (2014). The capital structure decision is regarding the manager policy in determining the proper proportion between the debt and the amount of equity capital in the company in order to maximize the value of the company. In contrast to Yuliana (2013) who obtained the findings that the capital structure has no significant negative effect on firm value. The use of debt is sensitive and tailored to the business climate. Due to the use of debt the company can earn profits and losses. This means that the debt has no effect on the level of the value of the company, because if the cost of the interest charged exceeds the benefit provided of debt is used, then the use of debt would harm caused by conditions or unfavorable business climate (Hardiningsih \& Sofyaningsih, 2011).

Another financial decision that companies used to increase the value of the company is cash holding. Ginglinger and Saddour (2008) mentioned that holding cash is the amount of cash held by the company to run the company's activities. This is valuable information for investors in making investment decisions. Withhold cash too large to pose a risk as the decline in the exchange rate are good for goods, services, and foreign currencies.

Previous research on the effect of holding cash against the value of the company has done Lee and Lee (2009) showed the value of a company that is proxied by Tobins' $Q$ negatively affected by cash holding. The results show that companies with high cash holdings caus- ed investors worried that more managers have the power to waste resources on projects that damage the company's enterprise value. These results are supported by Kalcheva and Lins (2007). However, in another study conducted by Srinivasan (2014) showed that cash holding has a significant positive effect on firm value.

Implementation of Good Corporate Governance (GCG) encourages the creation of healthy competition and good business climate. Therefore, implementation of GCG by companies in Indonesia is very important to support the growth and sustainable economic stability. Implementation of GCG is also expected to support the government's efforts to uphold good governance in Indonesia. Research conducted by Bauer et al. (2003), Amman et al. (2011), Retno and Priantin (2012), and Randy (2013) shows the results that there is a significant positive relationship between the variables with the company's corporate governance. While in the research Dittmar and Mahrt-Smith (2007) indicates that corporate governance can enhance shareholder value by applying cash holding function properly.

In this study, GCG will be the third proxy variables such as previous research conducted by Isshaq et al. (2009). Corporate governance mechanism can be seen from the 3 proxies or indicators such as board size (the size of the board), board independence, and the board or meetings intensity (the amount of the company's board meeting attendance). The results of this study indicate that there is a significant and positive relationship between the variables of corporate governance that is the size of the board of directors and board meetings with the firm value, but there is a negative relationship between the boards independence with the firm value.

Amanti and Venusita (2012) states that corporate governance significantly negatively related to firm value. This may be due to the company's practice of corporate governance is implemented, but implementation is not yet fully implemented by the company in accordance with the principles of GCG, or it can be said 
that the practice of good corporate governance implemented by the company as a formality (Amanti \& Venusita, 2012).

Results of previous studies show that there are differences in the results of research (research gap) about the factors that affect the value of the company, so that researchers interested in conducting further research on the effect of profitability, capital structure, cash holding, and GCG (proxied by the size of the board of directors, board independence, and the board intensity) against the value of the company.

\section{Hypothesis Development}

\section{Signalling Theory}

Brigham and Houston (2006) explain that the signaling theory is an action taken by the management company to give guidance to investors about how management views the company's prospects. This has been done by the management to realize the wishes of the owner. The signal can be known through the information about a company's good compared to other companies.

According Rahayu and Andri (2010) urge the company to provide information, because there is asymmetry of information between the company and outsiders because companies know more about the company and upcoming prospect than outsiders (investors, creditors). For investors, this information is important to determine investment decisions will be made. In this study, the signaling theory is used to examine the effect of profitability and capital structure of the company's value.

\section{Trade-off Theory}

The trade-off theory states that the company is trying to balance between the advantages of reduced taxes for the interest on the debt at the cost of financial difficulties due to the high proportion of debt (Najmudin, 2011). The trade-off theory shows that the value of the company with debt will increase with increasing debt.

The trade-off theory in conjunction with cash holding, this theory suggests that the company will maximize the value of the company based on the consideration of the costs and benefits of holding cash. The amount of cash holdings of a company due to the benefits derived from transactional motive and precautional motive. The advantage of the transactional motive company is able to save on transaction costs by using cash as a payment instrument apart from having to liquidate assets. While the precautional motive showed the company could collect more cash reserves to avoid the risk in the future or financial activity and investment.

\section{Agency Theory}

Corporate governance mechanisms are often associated with agency theory, which is where the principals in this case the owner of the company delegate operational responsibility to the company's agents in this case the manager (Kusumaningtyas \& Yendrawati, 2015). Agency relationship is the basis of the perspective that is used to understand corporate governance. Agency theory explains where the agency relationship arises when one or more persons (the principal) employ another person (the agent) to provide a service and then delegate decision-making authority to the agent (Randy, 2013). The relationship between the agent and the principal is built so that the company's goals can be achieved with the maximum. Herawaty (2009) suggested a separation of ownership by the principal to the control of the agent

\section{Firm Value}

According to Wibowo and Aisjah (2014) the value of the company is the achievement of a company as an indicator of the confidence of the shareholders of the company since the establishment of the company to date. Meanwhile, according to Sujoko and Soebiantoro (2007) the value of the company is an investor perception of the level of success of companies that are often associated with stock prices.

Based on the understanding that it can be concluded that the value of the company is an achievement of the founding of the company is reflected in stock prices to raise investors' positive perception of the company. The indi- 
cator used to measure the value of the company is Tobin's Q ratio is considered to provide the most information is good, because in Tobin's $Q$ include all elements of debt and equity shares of the company.

According to Sujoko and Soebiantoro (2007) the profitability is the company's ability to generate net income from the activity undertaken in the accounting period. Profitability is also a picture of a company in the management of the company, so the profitability of an indicator of management performance in managing the company's assets represented by the profit generated. In this study, the profitability will be proxied by Return on Equity (ROE). Brigham and Houston (2006) stated that the Return on Equity (ROE) is the ratio of net income to ordinary equity to measure the return on investment of ordinary shareholders.

H1: Profitability has a positive influence on firm value

According to Horne and Wachowicz (2010) the capital structure is a mix (proportion) of long-term permanent financing companies represented by debt, preferred stock equity, and common stock equity. Basically the company's funding decision with regard to the determination of the sources of funds used to finance the investment proposals that have been decided in advance. If the company meets the needs of their funds from internal sources, then the company is doing internal funding in the form of retained earnings. Conversely, if the company meets the needs of their funds from external sources, then the company does external financing. In this research, capital structure is proxied by Debt to Equity Ratio (DER). DER is a ratio used to measure the level of leverage (use of debt) to total shareholders' equity of the company (Hidayati, 2010).

H2: Capital Structure has a positive influence on firm value

Cash holding is an activity to withstand a certain amount of cash in the company. Ginglinger and Saddour (2008) mentions cash hol- ding is the amount of cash held by the company to run the company's activities.

$\mathrm{H} 3$ : Cash holding has a positive influence on firm value

Forum for Corporate Governance (FCGI) in the first publication uses the definition of Cadbury Committee, the GCG is a set of rules created to govern the relationship between shareholders, managers, creditors, governments, and other stakeholders associated with the rights and responsibility, or in other words a system to regulate and control the company (FCGI, 2014). In this study, GCG can be seen from three proxies or indicators such as board size, board independence, and the board meetings or intensity.

The size of the board of directors is a number of members of the board of directors of the company, which is specified by the number of units (Isshaq et al., 2009). Each member of the board of directors can perform their duties and make decisions in accordance with the division of duties and responsibilities. However, the implementation of tasks by each member of the board of directors remains a shared responsibility.

H4a: GCG proxied by board size has a positive influence on firm value

The Independent Board is a board member who has no affiliation with the other commissioners, independent board members, and the controlling shareholder (Samsul, 2006). The number of independent directors must be at least $30 \%$ of the commissioners.

$\mathrm{H} 4 \mathrm{~b}$ : GCG proxied by independent board has a positive influence on firm value

The intensity of the Board can be interpreted how often a company has a meeting. The board meeting is a process through which the commissioners in making a decision regarding company policy. Meetings held by the board of commissioners aimed at controlling and monitoring the policies that have been taken by the board of directors and its implementation. 
H4c: GCG proxied by board intensity has a positive influence on firm value

High profitability of the company will demonstrate a good prospect of the company and eventually generate higher net income. The higher the profit will be reflected in the increase in ROE which indicates the potential for increased corporate profits. According Mardiyati et al. (2012) the higher the profits obtained, the shareholders have the perception that the company is already doing its efficiency in using its assets, so as to generate a profit. Increasing ROE can trigger an increase in stock prices, because this condition is seen as a positive signal to investors to invest in the company.

While in the capital structure explained if the optimal capital structure will affect the profit increases. Profit increases will give a positive signal to investors, so that the share price increase and enhance shareholder value. Achievement of optimal capital structure of the company is to increase the proportion of debt that will lead to selection (trade-off) between corporate profits over the tax savings. Profits of companies that increase will boost the share price. Stock price increases will increase the value of the company.

Companies can also maximize the value of the company based on the consideration of the costs and benefits of holding cash. The company set the optimal level desired cash holding company, the management through active approach can make decisions on cash holdings based on a cost benefit analysis. The financial performance of the company will increase as a result of the optimal cash management. Financial performance increases will increase the stock price so the value of the company increases.

Good Corporate Governance (GCG) proxied be the size of the board of directors, independent board, and the intensity of the board. If the size of the board of directors, independent board, and the intensity of the board have been effective in a company, it will produce the optimal corporate governance. Optimal corporate governance will enhance the company's performance. Good performance will get a positive response from investors so that investors can assess by themselves the value of the company's shares compared with the book value of the company. The company's shares will rise and increase the value of the company.

\section{METHOD}

This research was causally emphasis on the quantitative determination of causality. The data used are secondary data from annual reports and financial statements of a firm in property and real estate sector is obtained from the Indonesia Stock Exchange.

The population in this study is property and real estate firms that listed in Indonesia Stock Exchange (IDX) in the period of 20082013. The samples in this study conducted by purposive sampling method of sampling with the intent and purpose set by the researchers. Samples criteria that used in this study are property and real estate firm which has consecutive annual report period 2008-2013 along with information regarding the size of the GCG board of directors, independent board, and the intensity of the board. There are seven companies that will be used for this research.

The dependent variable in this study is the value of the company is proxied by Tobin's Q. The independent variables in this study is the profitability, capital structure, cash holding, and GCG proxied by the size of the board of directors, independent board, and the board intensity.

The value of firms is an achievement of the founding of the company is reflected in stock prices to raise investors' positive perception of the company. The value of the company will be proxied by Tobin's $Q$ is calculated by the following formula:

$$
\mathrm{Q}=\frac{\mathrm{MVE}+\mathrm{D}}{\mathrm{BVE}+\mathrm{D}}
$$

Profitability is the company's ability toProfitability is the company's ability to generate net income from the activity undertaken in 
Prana Wahyu Nisasmara \& Musdholifah / Cash Holding, Good Coperate Governance...

the accounting period (Sujoko \& Soebiantoro, 2007). Profitability will be proxied by ROE is calculated by the following formula:

$$
\mathrm{ROE}=\frac{\text { Earning After Tax }}{\text { Equity }}
$$

The capital structure is a mix (proportion) long-term permanent financing companies represented by debt, equity preferred stock, and common stock equity (Horne \& Wachowicz, 2010). The capital structure will be proxied by DER calculated by the following formula:

$$
\text { Debt to Equity Ratio }=\frac{\text { Total Debt }}{\text { Total Equity }}
$$

Cash holding is an activity to withstand a certain amount of cash in the company. Cash holding can be measured by the log of cash and cash equivalents.

Cash holding $=\log$ ( cash and cash equivalents)

The size of the board of directors of a number of members of the board of directors of the company, which is specified by the number of units (Isshaq et al., 2009). Formulated as follows:

\section{Bdsize $=\log \sum$ Number of Board Director}

Independent board is measured by the ratio between the number of independent board compared with the number of commissioners in the company, expressed in the form of units (Isshaq et al., 2009). Formulated as follows:

$$
\text { Independent Board }=\frac{\sum \text { Number of Independent Board }}{\sum \text { Number of Commisioner Board }}
$$

The Board intensity is how often a company has a meeting. The effectiveness of these meetings can be affected by several factors such as the frequency of meetings of the board of commissioners, and behaviors of commissi- oners around conducting meetings, such as attendance at meetings, preparation for meetings, and participation of members in meetings.

Proportion Board Attendance $=\frac{\text { Each Board Attendance }}{\sum \text { Board Meeting }}$

Independent Board $=\frac{\sum \text { Proportion Board Attendance }}{\sum \text { Board Meeting }}$

Data analysis technique used in this research is multiple linear regression analysis previously performed classical assumption test, which includes normality test, multicollinearity, autocorrelation and heteroskedatisitas test. Multiple linear regression analysis using the program processed by Statistics Product and Service Solutions (SPSS) 19. Simultaneous and partial significance test, regression equation and the coefficient of determination test are performed after fulfilling the classical assumption test.

\section{RESULT AND DISCUSSION}

Based on the test result of the classical assumption obtained by the graph analysis showing the pattern of normal distribution, it can be seen that the dots indicating data spread around the diagonal line and follow the direction of the diagonal line. While the value of K-S (Kolmogorov-Smirnov) is 0.497 which value is greater than 0.05 so it can be concluded that the data were normally distributed. Multicoloniarity test results show the value of tolerance is more than 0.10 and VIF is less than 10 . so it can be concluded that no symptoms of the regression model multicoloniarity.

Autocorrelation test results using the test Durbin Waston (DW) obtained DW value of 2.782 satisfies the equation $4-\mathrm{du}<\mathrm{d}<4-\mathrm{dl}$ is $2.1549<2.782<2.7978$, which means that there is a positive correlation in the regression model. Due to the results did not meet the requirements, then it repaired using the lag of the residual obtained a yield of 2.020 satisfying the equation $\mathrm{du}<\mathrm{d}<4-\mathrm{du}$ is $1.8451<2.020<$ 2.1549 . Based on these equations, the regressi- 
on model is not autocorrelation. Heteroscedasticity test using a scatter graph shows that the data points spread above and below or around the numbers of 0 only and does not form a pattern. While on glejster test, the significance value is greater than 0.05 . It can be concluded that the regression model does not contain any heteroscedasticity. Multiple linear regression analysis of the results obtained in Table 1.

Table 1. Statistical Result

\begin{tabular}{lcccc}
\hline \multicolumn{1}{c}{ Variables } & Sig. F & Sig.t & $\mathbf{T}$ & $\left(\mathbf{R}^{2}\right)$ \\
\hline Regression & 0.000 & & & 0.525 \\
Profitability & & 0.181 & 1.365 & \\
Cap_Structure & & 0.007 & 2.843 & \\
Cash_Holding & & 0.237 & 1.202 & \\
Board_Size & & 0.021 & 2.425 & \\
Board_Indep & & 0.005 & 2.991 & \\
Meeting & & 0.399 & 0.853 & \\
\hline
\end{tabular}

Based on the multiple linear regression analysis in Table 1 showed that the F test of 0.000 where the value of less than 0.05 indicates that independent variables (profitability, capital structure, cash holding, and GCG proxied by the size of the Board of Directors, independent Board, and the Board intensity) affect the dependent variable (firm value) simultaneously.

The $t$-test showed that profitability does not affect the value of companies in which a significant level of $0.181>0.05$. Capital structure affects the value of companies in which the level of significance $0.007<0.05$. Cash holding does not affect the value of companies in which a significant level of $0.237>0.05$. The size of the board of directors affects the value of companies in which the level of significance of $0.021<0.05$. Independent board affects the value of companies in which the level of significance $0.005<$ 0.05 . The intensity of the board does not affect the value of companies in which a significant level of $0.399>0.05$. The regression equation as follows:

Firm Value $=-2.274+0.302$ Cap_Structure + 1,199 Board_Size +1.172 Board_Indep $+\mathrm{e}$
The amount of $\mathrm{R} 2$ is 0.525 or $52.5 \%$ means that the ability of the model to explain variations in the dependent variable by $52.5 \%$, which means that $52.5 \%$ of companies affected by the value of the variable profitability, capital structure, cash holding, and GCG proxied by the size of the board of directors, independent board, and the intensity of the board, while the remaining $47.5 \%$ is explained by other variables outside the regression model.

\section{The Effect of Profitability on Firm Value}

This study found that there is no effect between the profitability on firm value. In this study, the profitability measured by ROE to assess the profitability of the company based on efficiency in the use of equity. However, the absence of significant effect shows that the greater the profitability of a company then it will not affect the amount of value of the company. The results of this study indicate that the investor hopes to return in the foreseeable future is not affected by the size of firm value. Investors decided to buy company shares at a price that will tend to increase. The results of this study are not in line with the existing signaling theory that explains the relationship between profitability and firm value.

Although most of the research data showed ROE has increased every year, but this does not affect the value of the company. The insignificant impact on the profitability of the firm value is also supported by previous research conducted by Sambora (2014). This study identified that the shareholders have to take into account the amount of value of ROE, because the amount of ROE affects stock price changes in the stock market. Same result, Wibowo and Aisjah (2014) states that the partial profitability has no significant effect on the value of the company.

\section{The Effect of Capital Structure on Firm Value}

Based on the multiple linear regression analysis proved that there is a positive and significant impact of capital structure on the firm value. When viewed from the direction of the 
relationship, the regression coefficient with a positive direction explains that the more optimal capital structure of a company, the higher the value of the company. Optimal capital structure can maximize the balance between risk and return. Thus maximizing the share price is established by balancing the benefits of tax savings over the use of debt to bankruptcy costs. This positive effect shows that increasing debt has a positive signal to investors and it affected the firm value.

The positive influence between capital structure and firm value is also in accordance with the signaling theory which states that the company is able to generate profits tend to increase the debt due to the additional interest paid will be offset by income before taxes. The positive influence of capital structure to the company's value is also supported by previous studies conducted Santi (2011) states that the use of debt in the capital structure provides the company the opportunity to grow, thus increasing investment and affects the value of the company. In addition, research is also supported by Chen (2002), Antwi et al. (2010), Chowdhury and Chowdhury (2010), as well as Hoque et al. (2014) which states that the capital structure had a significant positive effect on firm value.

\section{The Effect of Cash Holding on Firm Value}

Testing the hypothesis regarding the effect of cash holding on firm value showed no significant relationship between cash holding and firm value. This result explains that regardless of the amount of cash holding does not affect the rise and fall of the firm value. In general, companies are financially controlled by the corporate governance tend to invest more cash and spend the available cash faster. Therefore, weaker corporate governance has consequences on cash management, so managers on weak corporate governance have smaller cash reserves. The results of this study do not support the theory that describes the trade off between cash holding relationship with the value of the company.

The insignificant effect on the value of cash holding companies is also supported by previous research conducted by Kalcheva and
Lins (2007), Lee and Lee (2009) shows the results of research that cash holding cash had no significant effect on firm value. Similarly, Isshaq et al. (2009) stated that cash holding does not affect the value of the company.

\section{The Effect of Board Size on Firm Value}

Testing hypothesis about the board size and firm size to prove that there is a positive and significant correlation between the board size on firm value. When viewed from the direction of the relationship, it has a positive effect means that the optimal proportion of the size of the board of directors of a company, the higher the value of the company. The positive correlation between the board size and firm value is according to the agency theory.

Purnamasari and Ardiana (2014) states that the addition of one member of the Board at the board size, either from the board of directors, independent board of commissioners as well as non-independent can improve the effectiveness of decision-making. The same result was shown by previous studies conducted Isshaq et al. (2009) showed that the board size or the size of the board of directors has a significant positive effect on firm value.

\section{The Effect of Board of Independent on Firm Value}

Based on the result of multiple linear regression analysis found significant levels is lower 0.05 , indicating independent board has a positive and significant effect on firm value. When viewed from the direction of the relationship, it has a positive effect means that the more optimal proportion of independent board of a company, the higher the value of the company. The presence of independent board of a company in large numbers indicates that the company is able to perform a supervisory function that is getting better. The positive influence between independent board and firm value can be explained by agency theory which states that the optimal proportion of the board of directors shows that the company is able to perform the supervisory function better. 


\section{The Effect of Board Intensity on Firm Value}

This study found that there is no effect between the intensity of the board on the firm value. The absence of significant effect showed that irrespective of the intensity of the board of a company then it will not affect the amount of value of the company. The results were not significant between the intensity of the board with the company's value because not all investors regard it as an indicator for assessing the prospects of a company.

This result is not supported by the agency theory that explains the increasingly fierce intensity on the board of a company can minimize the conflicts between various parties and have a positive impact on the board of directors that will work more effectively, so as to improve the performance and increase the value of the company.

\section{CONCLUSIONAND RECOMMENDATION}

Based on this study, profitability does not affect the firm value. High and low profitability as measured by ROE will not affect the amount of the firm. This research shows that companies that have small ROE does not mean the tobins'q are very low. This indicates that investors are not so considering the size of the company's when making an investment.

Capital structure has a significant positive effect on firm value. It means that the higher capital structure of the firm, the higher firm value. A positive influence suggests that investors in making investment decision considering the size of the capital structure as measured using DER.

Cash holding does not affect the firm value. The level of cash holding of a firm will not affect the amount of firm value. This indicates that the size of cash holding in a firm is not considered by the investor investment decision.

GCG proxied by the size of the board of directors has a positive significant effect on firm value. The more optimal proportion of size of the board of directors in a company, the higher firm value. This suggests that the optimal proportion of the board size considered by investor decision making.
GCG proxied by an independent board has a positive and significant impact on firm value. The more optimal proportion of independent board of a company, the higher the firm value. This indicates that the optimal proportion of independent board considered by investors in making investment.

GCG proxied by board intensity does not affect the firm value. Any intensity of the board of a company then it will not affect the amount of firm value. This shows that the amount of the intensity of the board is not considered by investors in making investment.

This study has several limitations, among others; there are some variables that are not significant and the low value of the coefficient of determination. Based on these limitations it is suggested for further research using and adding in addition to ROE ratios as an indicator to measure the profitability variable and choose the ratio of cash holding others as a tool to measure variables of cash holding in order to be more effective in the disclosure of the effect on firm value.

\section{REFERENCES}

Amanti, L \& Venusita, L. 2012. Pengaruh Good Corporate Governance Terhadap Nilai Perusahaan dengan Pengungkapan Corporate Sosial Responsibility Sebagai Variabel Pemoderasi (Studi Kasus pada Perusahaan Rokok yang Terdaftar di BEI). Jurnal Akuntansi Unesa. 1 (1): 1-21.

Amman, M., Oesch, D \& Schmid, M. M. 2011. Corporate Governance and Firm Value: International Evidence. Journal of Empirical Finance. 18 (1):36-55.

Antwi, S., Mills, E. F. E. A \& Zhao, X. 2012. Capital Structure and Firm Value: Empirical Evidence from Ghana. International Journal of Business and Social Science. 3 (22): 103-111.

Astuti, L \& Setiawati, E. 2014. Analisis Pengaruh Profitabilitas, Kebijakan Deviden, Kebijakan Hutang, dan Kepemilikan Manajerial Terhadap Nilai Perusahaan (Studi Empiris pada Perusahaan Manufaktur yang Terdaftar di Bursa Efek Indonesia Tahun 2010-2012). Proceedings. National Seminar and Call for 
Prana Wahyu Nisasmara \& Musdholifah / Cash Holding, Good Coperate Governance...

Paper, Accounting-FEB UMS, 25 June 2014.

Bauer, R., Guenster, N \& Otten, R. 2003. Empirical Evidence on Corporate Governance in Europe: The Effect on Stock Returns, Firm Value and Performance. Journal of Asset Management. 5 (2): 91-104.

Brigham, E. F \& Houston J. F. 2006. Dasar-Dasar Manajemen Keuangan. $10^{\text {th }}$ Ed. Jakarta: Salemba Empat.

Chen, K. K. 2002. The Influence of Capital Structure on Company Value with Different Growth Opportunities. 1 (1): 1-14.

Chowdhury, A \& Chowdhury, S. P. 2010. Impact of Capital Structure on Firm's Value: Evidence from Bangladesh. Business and Economic Horizons. 3 (3): 111-122.

Dittmar, A \& Mahrt-Smith, J. 2007. Corporate Governance and the Value of Cash Holdings. Journal of Financial Economics. 83 (3): 599634.

FCGI. 2014. What is Corporate Governance. Available at $h t t p: / / w w w . f c g i . o r . i d / c o r p o r a t e-g o v e r-$ nance/about-good-corporate-governance.html. 5 Desember 2014.

Ginglinger, E \& Saddour, K. 2008. Cash Holdings, Corporate Governance and Financial Constraints. http://ssrn.com.abstract $=1188843$ or http://dx.doi.org/10.2139/ssrn.11188843.

Hardiningsih, P \& Sofyaningsih, S. 2011. Struktur Kepemilikan, Kebijakan Dividen, Kebijakan Utang dan Nilai Perusahaan. Dinamika Keuangan dan Perbankan. 3 (1): 68-87.

Herawaty, V. 2009. Peran Praktek Corporate Governance Sebagai Moderating Variable dari Pengaruh Earnings Management Terhadap Nilai Perusahaan. Jurnal Akuntansi dan Keuangan. 10 (2): 97-108.

Hidayati, E. E. 2010. Analisis Pengaruh DER, DPR, ROE dan Size Terhadap PBV Perusahaan Manufaktur yang Listing di BEI Periode 2005-2007. Dissertation. Semarang: Universitas Diponegoro.

Hoque, J., Hossain, A \& Hossain, K. 2014. Impact of Capital Structure Policy on Value of the Firm-A Study on Some Selected Corporate Manufacturing Firms Under Dhaka Stock Exchange. Ecoforum Journal. 3 (2): 77-84.

Horne, J. C. V \& Wachowicz, J. M. 2010. Financial Management. Jakarta: Salemba Empat.

Isshaq, Z., Bokpin, G. A \& Onumah, J. M. 2009. Corporate Governance, Ownership Struc- ture, Cash Holding, and Firm Value on the Ghana stock Exchange. The Journal of Risk Finance. 10 (5): 488-499.

Kalcheva, I \& Lins, K. V. 2007. International Evidence on Cash Holdings and Expected Managerial Agency Problems. Review of Financial Studies. 20 (4): 1087-1112.

Kusumajaya, D. K. O. 2011. Pengaruh Struktur Modal dan Pertumbuhan Perusahaan Terhadap Profitabilitas dan NilaiPerusahaan pada Perusahaan Manufaktur di Bursa Efek Indonesia. Thesis. Denpasar: Universitas Udayana.

Kusumaningtyas, R \& Yendrawati, R. 2015. The Effect of Company Diversification Toward Earning Management Moderated by Managerial Ownership. Jurnal Dinamika Manajemen. 6 (2): 178-186.

Lee, K. W \& Lee, C. F. 2009. Cash Holdings, Corporate Governance Structure and Firm Valuation. Review of Pacific Basin Financial Markets and Policies. 12 (3): 475-508.

Mardiyati, U., Ahmad, G. N \& Putri, R. 2012. Pengaruh Kebijakan Dividen, Kebijakan Hutang dan Profitabilitas Terhadap Nilai Perusahaan Manufaktur yang Terdaftar di Bursa Efek Indonesia (BEI) Periode. Jurnal Riset Manajemen Sains Indonesia (JRMSI). 3 (1): 1-17.

Najmudin. 2011. Manajemen Keuangan dan Akuntansi Syar'iyyah Modern. Yogyakarta: ANDI.

Purnamasari, A. A \& Ardiana, P. A. 2014. Pengaruh Board Size Terhadap Nilai Perusahaan. EJurnal Akuntansi Universitas Udayana. 7 (1): 177-191.

Rahayu, S \& Andri, A. 2010. Pengaruh Kinerja Keuangan Terhadap Nilai Perusahaan dengan Pengungkapan Corporate Social Responsibility dan Good Corporate Governance Sebagai Variabel Pemoderasi (Studi Empiris Pada Perusahaan Manufaktur di Bursa Efek Jakarta). Dissertation. Semarang: Universitas Diponegoro.

Randy, V. 2013. Pengaruh Penerapan Good Corporate Governance Terhadap Nilai Perusahaan 2007-2011. Business Accounting Review. 1 (2): 306-318.

Retno, R. D \& Priantinah, D. 2012. Pengaruh Good Corporate Governance dan Pengungkapan Corporate Social Responsibility Terhadap Nilai Perusahaan (Studi Empiris pada Perusahaan yang Terdaftar di Bursa Efek Indonesia Periode 2007-2010). Nominal: Barometer Ri- 
set Akuntansi dan Manajemen. 1 (1): 84-103.

Sambora, M. N. 2014. Pengaruh Leverage dan Profitabilitas Terhadap Nilai Perusahaan (Studi pada Perusahaan Food and Beverages yang Terdaftar di BEI Periode Tahun 2009-2012). Jurnal Administrasi Bisnis. 8 (2): $1-10$.

Samsul, M. 2006. Pasar Modal \& Manajemen Portofolio. Jakarta: Erlangga.

Santi, N. 2011. Analisis Pengaruh Struktur Modal, Pertumbuhan Perusahaan, Ukuran Perusahaan, dan Profitabilitas Terhadap Nilai Perusahaan. Thesis. Semarang: Universitas Diponegoro.

Sari, O. T. 2013. Pengaruh Keputusan Investasi, Keputusan Pendanaan dan Kebijakan Dividen terhadap Nilai Perusahaan. Management Analysis Journal. 2 (2): 1-7.

Sujoko \& Soebiantoro, U. 2007. Pengaruh Struktur Kepemilikan, Leverage, Faktor Intern, dan Faktor Ekstern Terhadap Nilai Perusahaan (Studi Empirik pada Perusahaan Manufaktur dan Non Manufaktur di Bursa Efek Jakarta). Jurnal Manajemen dan Kewirausahaan. 9 (1): 41-48.
Srinivasan, G. 2014. Cash Holdings and Firm Value During Turbulent Times-Canadian Evidence. Available at SSRN 2430169.

Wahyuni, S. 2012. Efek Struktur Modal terhadap Profitabilitas pada Perusahaan Manufaktur yang Terdaftar di Bursa Efek Indonesia. Management Analysis Journal. 1 (2): 29-33.

Wardoyo \& Veronica, T. M. 2013. Pengaruh Good Corporate Governance, Corporate Social Responsibility dan Kinerja Keuangan terhadap Nilai Perusahaan. Jurnal Dinamika Manajemen. 4 (2): 132-149

Wibowo, R \& Aisjah, S. 2014. Pengaruh Profitabilitas, Kepemilikan Manajerial, Kebijakan Dividen, dan Leverage Terhadap Nilai Perusahaan (Studi pada Perusahaan Manufaktur yang Terdaftar di Bursa Efek Indonesia Periode 2009-2011). Jurnal Ilmiah Mahasiswa FEB. 2 (1): 1-14.

Yuliana, Y. 2013. Pengaruh Struktur Modal dan Return on Equity (ROE) terhadap Nilai Perusahaan pada Perusahaan Sektor Pertanian di Bursa Efek Indonesia (Perusahaan Yang Terdaftar Di BEI). Unpublished Thesis. Palembang: STIE MDP. 